\title{
HASIL BELAJAR MATEMATIKA SISWA MENGGUNAKAN JEDA STRATEGIS DENGAN TEKA-TEKI DI KELAS X IPK MAN 1 PAYAKUMBUH TAHUN PELAJARAN 2018/2019
}

\author{
Bella Putri Utami ${ }^{1}$, Aniswita ${ }^{1}$, Gema Hista Medik ${ }^{1}$ \\ ${ }^{1}$ Institut Agama Islam Negeri Bukittinggi, Jl. Gurun Aua, Kubang Putiah, Kota Bukittinggi 26117, Indonesia \\ Email: bellaputriutami195@gmail.com
}

\begin{abstract}
Abstrak
Penelitian ini di latarbelakangi oleh adanya permasalahan yang ditemukan di kelas X IPK MAN 1 Payakumbuh berdasarkan observasi dan wawancara yang telah dilakukan yaitu matematika merupakan pembelajaran yang membosankan bagi siswa, kurang konsentrasinya siswa selama proses pembelajaran, dan rendahnya hasil belajar siswa. Salah satu upaya yang dapat mengatasi masalah tersebut adalah pembelajaran menggunakan jeda strategis dengan teka-teki didalam pembelajaran matematika. Penelitian ini bertujuan untuk mengetahui hasil belajar menggunakan jeda strategis dengan teka-teki lebih baik dari pada tanpa jeda strategis di kelas X IPK MAN 1 Payakumbuh. penelitian ini adalah pra-eksperimen dengan rancangan The Static Group Comparison Only Design. Data penelitian ini diperoleh dari tes akhir . Hasil $t_{\text {hitung }}=3,58$ dan $t_{\text {tabel }}=1,68$, karena $t_{\text {hitung }}>t_{\text {tabel }}$ bearti $\mathrm{H}_{0}$ ditolak pada taraf nyata $\alpha=0,05$, serta dengan menggunakan software minitab diperoleh $\mathrm{P}_{\text {value }}=0,000$ yang artinya $\mathrm{P}_{\text {value }}<\alpha$ dengan $\alpha=0,05$. Dapat disimpulkan bahwa hasil belajar matematika siswa menggunakan jeda strategis dengan teka-teki lebih baik dari pembelajaran tanpa jeda strategis dengan teka-teki di kelas X IPK MAN 1 Payakumbuh.
\end{abstract}

Kata kunci: Jeda Strategis,Teka-teki, Hasil Belajar

\begin{abstract}
This research is based on the background of the problems found in class X IPK MAN 1 Payakumbuh based on observations and interviews that have been conducted, namely mathematics is boring learning for students, lack of concentration of students during the learning process, and low student learning outcomes. One effort that can overcome this problem is learning using strategic pauses with puzzles in mathematics learning. This study aims to find out the learning outcomes using strategic pauses with puzzles better than without strategic breaks in class $\mathrm{X}$ IPK MAN 1 Payakumbuh. this research is pre-experiment with the design of The Static Group Comparison Only Design. The research data was obtained from the final test. The results of tcount $=3.58$ and $t_{\text {table }}=1.68$, because $t_{\text {count }}>t_{\text {table }}$ means $H 0$ is rejected at the real level $\alpha=0,05$, and by using the Minitab software obtained Pvalue $=0,000$ which means Pvalue $<\alpha$ with $\alpha=0.05$. It can be concluded that the mathematics learning outcomes of students use strategic pauses with puzzles better than learning without strategic pauses with puzzles in class X IPK MAN 1 Payakumbuh .
\end{abstract}

Keywords: strategic pauses, puzzles, learning outcomes.

\section{PENDAHULUAN}

Pendidikan pada dasarnya adalah usaha sadar untuk menumbuh kembangkan potensi sumber daya manusia peserta didik dengan cara mendorong dan memfasilitasi kegiatan belajar mereka.(Muhibbin syah, 2012) Dalam Undang-Undang Sistem Pendidikan Nasional (UUSPN) Nomor 20 tahun 2003 tentang Sistem Pendidikan Nasional Bab 1 Pasal 1 (1) pendidikan didefinisikan sebagai "Usaha sadar dan terencana untuk mewujudkan suasana belajar dan proses belajar agar peserta didik secara aktif mengembangkan potensi dirinya untuk memiliki kekuatan spiritual keagamaan, pengendalian diri, kepribadian, kecerdasan, akhlak mulia, serta keterampilan yang diperlukan dirinya, masyarakat, bangsa dan negara." (Depdiknas, 2003) 
Pembelajaran membutuhkan sebuah proses yang disadari yang cenderung bersifat permanen dan mengubah perilaku. Pada proses tersebut terjadi pengingatan informasi yang kemudian disimpan dalam memori organisasi kognitif. Selanjutnya keterampilan tersebut diwujudkan secara praktis pada keaktifan siswa dalam merespon dan bereaksi terhadap peristiwa-peristiwa yang terjadi pada diri siswa ataupun lingkungan. (M.thobroni, 2015)

Penelitian Herman Nirwana mengungkapkan bahwa banyak siswa meninggalkan pelajaran matematika dibeberapa SMA di Sumatera Barat sebelum pelajaran selesai. Di antara empat mata pelajaran yang diteliti (Fisika, Kimia, Bahasa Inggris, dan Matematika), ternyata pada mata pelajaran matematika paling banyak siswa absen dan meninggalkan kelas sebelum pelajaran selesai. Hal ini menurut Herman, mengindikasikan bahwa mata pelajaran matematika termasuk salah satu mata pelajaran yang kurang disukai siswa(Dharmansyah, 2012)

Otak manusia dibagi menjadi otak kanan dan otak kiri. Proses berpikir otak kiri bersifat logis, sekuensial, linear, dan rasional. Cara berpikirnya sesuai dengan tugas-tugas teratur ekspresi verbal, menulis, membaca, asosiasi audiotorial, menempatkan detail dan fakta, fenometik serta simbiolisme. Cara berpikir otak kanan bersifat acak, tidak teratur, intuitif, dan holistik. Cara berpikirnya seperti perasaan dan emosi, kesadaran yang berkenaan dengan perasaan, kesadaran spasial, pengenalan bentuk dan dan pola, seni, kepekaan warna, kreativitas, dan visualisasi. (Bobbi Deporter dan Mike Hernacki, 2003) Dalam pembelajaran sangat penting adanya keseimbangan antara otak kiri dan otak kanan. Keseimbangan yang dihasilkan dapat menghilangkan stres, dan mendapatkan fisik yang baik. (Bobbi Deporter dan Mike Hernacki, 2003)

Pembelajaran yang menyenangkan akan memberikan dampak yang positif terhadap peningkatan efektivitas pembelajaran.(Dharmansyah, 2012)Salah satu pembelajaran yang diharapkan mewujudkan hal tersebut adalah pembelajaran matematika. Semakin senang seseorang terhadap suatu mata pelajaran, semakin tinggi motivasinya untuk mengikuti pelajaran tersebut maka semakin baik hasil belajarnya. (Dharmansyah, 2012). Menurut Dharmansyah, jeda strategis adalah istirahat sejenak (kurang lebih 3-5 menit) dalam proses pembelajaran setelah pembelajaran berjalan selama periode waktu 25-30 menit. (Dharmansyah, 2012) Dengan diberikan waktu jeda pembelajaran selama 5 menit atau lebih dapat membantu pemahaman bagi siswa karena adanya situasi segar dan menyenangkan, secara psikis membantu daya kerja otak dalam menyerap dan mempengaruhi hasil belajar. (Margaretha, n.d.) Sejalan dengan Deporter dan Hernacki:"Kita mengingat dengan sangat baik informasi yang diterima pada awal dan akhir sesi belajar. Jika dalam persentase 90 menit diadakan jeda setiap 30 menit, maka persentase daya ingat meningkat". (Bobbi Deporter dan Mike Hernacki, 2003)

Jeda strategis dengan teka-teki ini diterapkan dalam pembelajaran dengan menggunakan strategi ekspositori. Strategi pembelajaran ekspositori merupakan bentuk dari pendekatan pembelajaran yang berorientasi kepada guru, karena dalam strategi ini, guru memegang peran yang sangat dominan. Melalui strategi ini, guru menyampaikan materi pelajaran secara terstruktur dengan harapan materi pelajaran yang disampaikan itu dapat dikuasai siswa dengan baik.

Berdasarkan prosedur dalam strategi pembelajaran ekspositori, maka pelaksanaan jeda strategis dengan teka-teki ini di lakukan pada setiap pembelajaran berjalan 25-30 menit pada kegiatan inti pembelajaran. Setiap 25-30 menit sesi belajar diberikan jeda selama 3-5 menit, dan diisi dengan teka -teki yang diberikan oleh guru. Setelah jeda strategis dilaksanakan 3-5 menit, guru kembali melanjutkan pembelajaran.

Cara terbaik untuk menjaga daya ingat dan konsentrasi tetap terpelihara,maka jeda strategis harusnya diisi dengan kegiatan yang mendatangkan kesegaran. (Dharmansyah, 2012) Di saat jeda tersebut siswa dapat ditingkatkan kesegaran konsentrasi belajar dan daya ingat melalui kegiatankegiatan yang menyentuh emosi, seperti selingan musik, cerita-cerita lucu, humor dan lain-lain. (Dharmansyah, 2007)Pembelajaran yang menarik dan menyenangkan mampu memperoleh hasil 
belajar yang optimal, salah satunya dengan permainan teka-teki. (Wicka Yunita Putri Dwi Utami, 2013)

\section{METODE PENELITIAN}

Berdasarkan permasalahan yang telah dikemukakan, maka jenis penelitian ini adalah penelitian eksperimen. Penelitian eksperimen adalah penelitian yang mengadakan perlakuan (manipulasi) terhadap variabel penelitian (variabel bebas). Kemudian mengamati konsekuensi perlakuan tersebut terhadap objek penelitian (variabel terikat). (Lufri \& Ardi, 2015)Pada penelitian ini, penelitian eksperimen yang digunakan adalah pra eksperimen yaitu penelitian yang mengandung ciri eksperimental dalam jumlah yang kecil Pada penelitian ini kelompok eksperimen diberikan perlakuan berupa pembelajaran menggunakan jeda strategis dengan teka-teki, sedangkan pada kelompok kontrol dilakukan pembelajaran tanpa jeda strategis dengan teka-teki.

Populasi dalam penelitian ini adalah seluruh siswa kelas X IPK MAN 1 Payakumbuh. Untuk menentukan kelas sampel pada penelitian ini digunakan teknik Simple Random Sampling yaitu pengambilan sampel dilakukan secara acak, artinya setiap anggota populasi atau unit dalam populasi mendapat kesempatan yang sama untuk dipilih. Kertas yang pertama diambil adalah kelas kelas $\mathrm{X}$ IPK 1 kelas ini peneliti jadikan sebagai kelas eksperimen. Pada kejadian pengambilan kedua yang keluar adalah kelas X IPK 2, kelas ini peneliti jadikan sebagai kelas kontrol., sedangkan pengambilan ke tiga menjadi kelas uji coba yaitu kelas X IPK 3.

\section{HASIL PENELITIAN DAN PEMBAHASAN}

\section{A. Deskriptif Data}

\section{Hasil Belajar Matematika siswa}

Berdasarkan penelitian yang telah dilakukan di kelas X IPK MAN 1 Payakumbuh, kelas X IPK 1 merupakan kelas eksperimen dan kelas X IPK 2 merupakan siswa kelas kontrol. Dari hasil penelitian diperoleh data hasil belajar matematika siswa kelas X IPK 1 yang belajar menerapkan Jeda Strategis menggunakan teka teki dan hasil belajar siswa kelas X IPK 2 yang belajar menggunakan pembelajaran tanpa jeda strategis dengan teka teki. Penilaian hasil belajar dilakukan dengan menggunakan tes akhir berupa tes uraian sebanyak 4 butir soal.

Data mentah hasil tes akhir siswa kelas eksperimen dan kontrol dapat dilihat pada lampiran XXI halaman 197. Jumlah siswa yang nilainya di atas dan di bawah Kriteria Ketuntasan Minimal (KKM) dapat dilihat pada tabel 4.1 berikut:

Tabel 4.1.Nilai Tes Akhir Siswa Kelas Eksperimen Dan Kelas Kontrol Yang Di atas dan Di Bawah KKM

\begin{tabular}{|c|c|c|c|}
\hline Jumlah Siswa & KKM & Kelas Eksperimen & Kelas Kontrol \\
\hline Nilai yang di atas KKM & 76 & 15 & 7 \\
\hline Nilai yang di bawah KKM & & 9 & 16 \\
\cline { 3 - 4 } & & 24 & 25 \\
\cline { 3 - 4 } & & & \\
\hline
\end{tabular}

Berdasarkan tabel 4.1 di atas diperoleh perhitungan bahwa, pada kelas eksperimen siswa yang tuntas dalam belajar matematika sebanyak 15 orang dan 9 orang yang belum tuntas. Sedangkan pada kelas kontrol siswa yang tuntas dalam belajar matematika sebanyak 7 orang dan 16 orang yang belum tuntas. 
Persentase kelas sampel dapat digambarkan dengan diagram berikut ini :

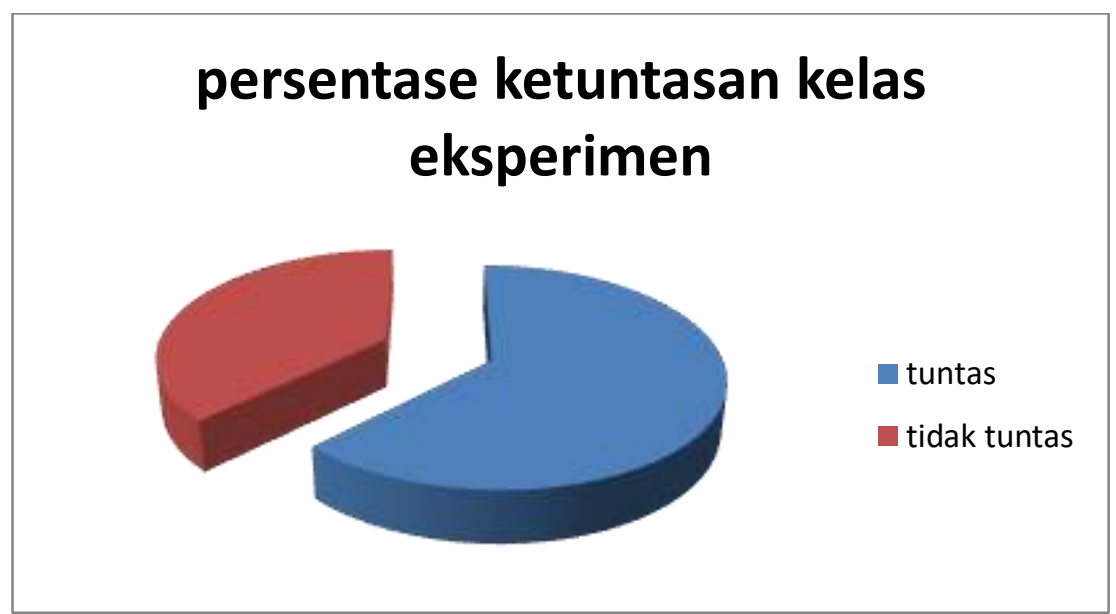

Gambar 4.1 diagram persentase ketuntasan kelas eksperimen

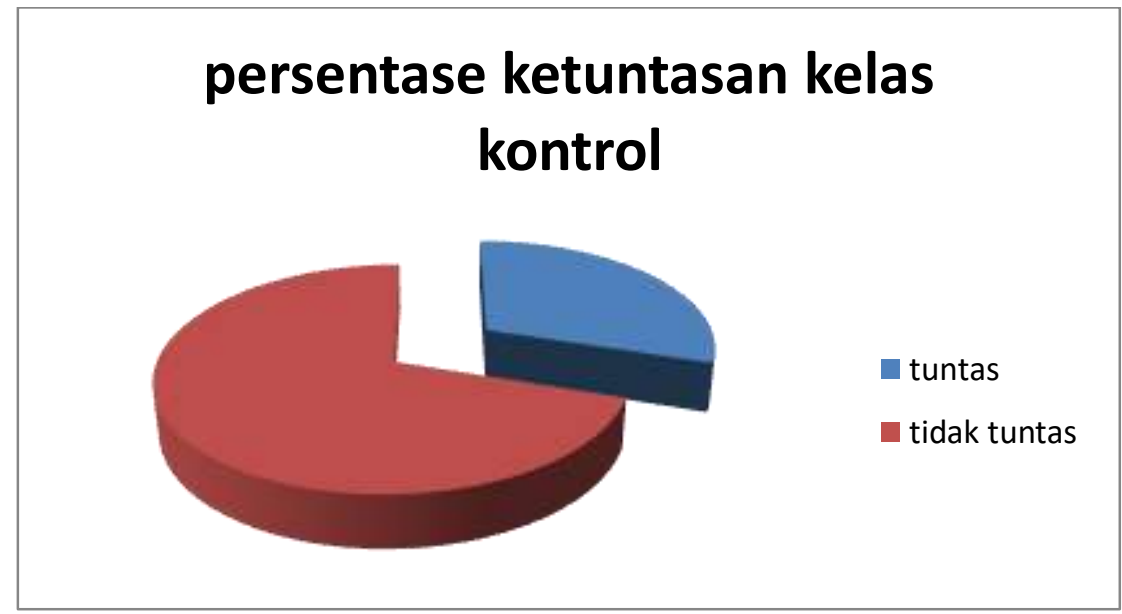

Gambar 4.2 diagram persentase ketuntasan kelas kontrol

Dari data mentah tes hasil belajar matematika siswa tersebut, diperoleh pula data mengenai rata-rata, standar deviasi, variansi, nilai maksimum dan nilai minimum dari kelas sampel seperti yang terdapat pada tabel 4.2 di bawah ini:

Tabel 4.2 Hasil Deskriptif Statistik Dari Data Tes Hasil Belajar

\begin{tabular}{|l|c|l|l|l|l|}
\hline Kelas & $\bar{X}$ & $\mathrm{~N}$ & $\mathrm{~S}$ & $\mathrm{X}_{\text {maks }}$ & $\mathrm{X}_{\min }$ \\
\hline Eksperimen & 76,125 & 24 & 12,986 & 98 & 43 \\
\hline Kontrol & 59,435 & 23 & 18,632 & 20 & 96 \\
\hline
\end{tabular}

Ketuntasan siswa kelas eksperimen lebih tinggi dari pada persentase ketuntasan siswa kelas kontrol. Pada kelas eksperimen, jumlah siswa yang tuntas ada 15 siswa atau 62,5\% dan yang tidak tuntas ada 14 siswa atau 37,5\% dari jumlah keseluruhan siswa kelas eksperimen yaitu 24 siswa. Sedangkan, pada kelas kontrol 7 siswa atau 30\% yang tuntas dan 16 siswa atau $70 \%$ tidak tuntas dari 23 siswa. 


\section{B. Analisis Data}

\section{Tes Hasil Belajar}

Analisis data tes hasil belajar dilakukan dengan menentukan uji normalitas tes hasil belajar pada kedua kelas sampel, yaitu kelas eksperimen dan kelas kontrol. Kemudian dilakukan uji homogenitas variansi dan langkah selanjutnya melakukan uji hipotesis. Setelah dilakukan uji hipotesis, barulah ditarik kesimpulan tentang hasil belajar yang dilakukan pada kedua kelas sampel.

\section{Uji Normalitas}

Uji normalitas bertujuan untuk mengetahui apakah sampel berdistribusi normal. Uji normalitas tes hasil belajar kelas eksperimen dan kelas kontrol dilakukan dengan menggunakan uji Lilliefors. Hasil analisis data pada taraf nyata $\alpha=0,05$ diperoleh $\mathrm{L}_{0}$ masing-masing kelas populasi seperti terlihat pada tabel berikut:

Tabel 4.3 Hasil Uji Normalitas Tes Hasil Belajar Kelas Sampel dengan Uji Lilliefors

\begin{tabular}{|l|l|l|c|l|}
\hline No & Kelas & $\mathbf{L}_{\mathbf{0}}$ & $\mathbf{L}_{\text {tabel }}$ & Keterangan \\
\hline 1 & Eksperimen & 0.1397 & 0.190 & Data berdistribusi normal \\
\hline 2 & Kontrol & 0.1203 & 0.190 & Data berdistribusi normal \\
\hline
\end{tabular}

Berdasarkan tabel 4.3 di atas terlihat bahwa kedua kelas sampel memiliki nilai $\mathrm{L}_{0}$ lebih kecil dari $\mathrm{L}_{\text {tabel. }}$ Sehingga dapat disimpulkan bahwa data kedua kelas sampel berdistribusi normal.

\section{Uji Homogenitas}

Perhitungan uji homogenitas dapat dilihat pada tabel dibawah ini

Tabel 4.4 Hasil Uji Homogenitas Tes Akhir Matematika Kelas Sampel

\begin{tabular}{|c|c|c|c|}
\hline $\mathbf{A}$ & $\mathbf{F}_{\text {tabel }}$ & $\mathbf{F}_{\text {hitung }}$ & Kesimpulan \\
\hline 0,05 & 4,08 & 0,49 & Variansi homogen \\
\hline
\end{tabular}

berdasarkan tabel diatas diperoleh bahwa $\mathrm{F}_{\text {hitung }}<\mathrm{F}_{\text {tabel }}$ maka diperleh data bervariansi homogen.

\section{Uji Hipotesis}

Setelah diketahui bahwa kedua kelas sampel berdistribusi normal dan memiliki variansi yang homogen, maka selanjutnya dilakukan uji hipotesis dengan menggunakan uji-t. Hasil perhitungan uji hipotesis dengan uji-t pada kedua kelas sampel diperoleh bahwa nilai $t_{\text {hitung }}=3,58$ dan nilai $t_{\text {tabel }}=$ $t_{(0.95,45)}$ adalah 1,68. Kriteria pengujian adalah terima $\mathrm{H}_{0}$ jika $t_{\text {hitung }}<t_{\text {tabel}}$, selain itu tolak $\mathrm{H}_{0}$. Berdasarkan perhitungan diperoleh $\mathrm{t}_{\text {hitung }}>\mathrm{t}_{(0.95,45)}$ yaitu $3,58>1,68$, sehingga $\mathrm{H}_{0}$ ditolak.

\section{PEMBAHASAN}

\section{Hasil Belajar Matematika}

Berdasarkan hasil deskripsi dan analisis data tes hasil belajar siswa terlihat bahwa hasil uji hipotesis yang menggunakan uji-t dan Software MINITAB. Perhitungan memperoleh bahwa tolak $\mathrm{H}_{0}$ karena diperoleh $t_{\text {hitung }}=3,58$ lebih besar dari $t_{\text {tabel }}=1,68$ dan nilai P-value $=0.000$ lebih kecil dari taraf nyata $\alpha=0,05$, sehingga dapat disimpulkan tolak $\mathrm{H}_{0}$ dengan arti kata "hasil belajar matematika 
siswa menggunakan jeda strategis dengan teka-teki lebih baik dari pada siswa yang mengikuti pembelajaran tanpa jeda strategis dengan teka-teki di kelas X IPK MAN 1 Payakumbuh "

Sejalan dengan pendapat Margaretha, dengan diberikan waktu jeda pembelajaran selama 5 menit dapat membantu pemahaman bagi siswa karena adanya situasi segar dan menyenangkan, secara psikis membantu daya kerja otak dalam menyerap dan mempengaruhi hasil belajar. pembelajaran yang menarik dan menyenangkan mampu memperoleh hasil belajar yang optimal salah satunya dengan permainan teka-teki [6]

Berdasarkan pengamatan peneliti selama peneltian, terlihat bahwa siswa pada kelas eksperimen lebih aktif dalam belajar dan lebih banyak ikut berpartisipasi dalam proses pembelajaran. Pada saat proses pembelajaran berlangsung siswa terlihat antusias untuk menjawab pertanyaanpertanyaan yang diberikan oleh guru, sehingga hasil belajar siswa meningkat.

\section{KESIMPULAN DAN SARAN}

Berdasarkan hasil penelitian pada bab IV dapat disimpulkan bahwa hasil belajar matematika menggunakan jeda strategis dengan teka teki lebih baik dari pada pembelajaran tanpa jeda strategis dengan teka teki di kelas X IPK MAN 1 Payakumbuh.

Diharapkan pembelajaran matematika dengan menggunakan jeda strategis dengan teka teki bisa dijadikan salah satu alternatif dalam penyampaian materi pelajaran kepada siswa dalam rangka meningkatkan hasil belajar matematika siswa

\section{REFERENCES .}

Bobbi Deporter dan Mike Hernacki. (2003). Quantum Learning :Membiasakan Belajar Nyaman dan Menyenangkan.

Depdiknas. (2003). No TitleUndang-Undang Sistem Pendidikan Nasional (UUSPN) Nomor 20 Tahun 2003.

Dharmansyah. (2007). Menciptakan Pembelajaran Menyenangkan Melalui Optimalisasi Jeda Strategis De ngan Karikatur Humor Dalam Belajar Matematika. Jurnal Teknodik.

Dharmansyah. (2012). Strategi Pembelajaran Menyenangkan dengan Humor.

Lufri \& Ardi. (2015). Metodologi Penelitian.

M.thobroni. (2015). Belajar dan Pembelaran.

Margaretha. (n.d.). Implementasi Eduitainment Untuk Menjadi Guru Idola. Insania, 18.

Muhibbin syah. (2012). Psikologi Belajar.

Wicka Yunita Putri Dwi Utami. (2013). meningkatkan Minat Belajar Matematika Melalui Permainan Teka-Teki. Jurnal Ilmiah, 18. 